\title{
Exploration Study of Cancer Hospital with Biophilic Design Approach in Bandarlampung
}

\author{
Suryo Bahwono Isyworo ${ }^{1}$, Ai Siti Munawaroh ${ }^{1}$ and Tjetjeng Sofjan Surjana ${ }^{1}$ \\ ${ }^{1}$ Architecture Department/ Faculty of Engineering, Universitas Bandar Lampung, Indonesia \\ aisiti.arch@ubl.ac.id
}

\begin{abstract}
Cancer is the most dreaded disease. It is because the disease is still arduous to cure and requires quite a long time in healing. This situation makes people with cancer experience severe depression. Therefore, we need a cancer hospital design that can reduce the level of depression. The purpose of this research aims to perform design exploration studies in cancer hospitals by applying the Biophilic architectural concept that is expected to reduce the level of depression. The methods used there are three, namely the study of literature, precedent studies, and field studies. The results showed that the Biophilic concept could be applied to the waiting room, inpatient unit, and site. In the waiting room, there is a void that leads directly to the pool below, wall coverings made of natural wood that seem deliberately not solid. So sunlight can get into the room. Inpatient unit room using a glass that can be opened that serves to incorporate light and the natural air. It used blue glass color for the purpose of applying the color of sky and water. On the site can be seen when the patient enters the hospital neighborhood atmosphere to be conveyed to the patient in a natural setting so that the first impression when entering hospital patients is not negative thinking. This research is limited to the application of Biophilic Architecture concepts in waiting rooms, inpatient rooms, and sites. Further research is needed regarding the implementation of Biophilic concepts in outpatient facilities and other facilities.
\end{abstract}

(C) 2018 IJBESR. All rights reserved.

Keywords: cancer, cancer hospital, biophilic design, bandarlampung

\section{Introduction}

Based on data that have been issued by the Ministry of Health of Indonesia on September 1, 2015, about the situation of Cancer explains that an increase in the number of cancer patients in Indonesia, from year to year. In Indonesia, the number of cancer patients is $1.4 \%$, and in Lampung, provinces amounted to $0.7 \%$, or 5.517 total population[1], whereas Lampung province has not had cancer hospital. A cancer patient who wants to do a therapy must go to Dharmais Cancer Hospital in West Jakarta. So that in this study wanted to design a cancer hospital to facilitate cancer patients in Lampung province.

\subsection{Formulations of the Problems}

How to explore the design of a cancer hospital in Bandarlampung, and how to apply Biophilic Architecture concept at the cancer hospital.

\subsection{Research Objectives}

To explore the design of cancer hospitals in Bandarlampung and to apply the concept of Biophilic Architecture at the cancer hospital.

\subsection{Overview of Theory}

\subsubsection{Cancer Hospital}

According to Minister of health regulation (Permenkes) No. 147 of 2010 on Licensing Hospital, Special Hospital is a hospital that provides primary care in one area or one particular type of disease based on disciplines, ages, organs, diseases or other specificities [2]. 
The medic unit to handle patients who have

Medical services that must be met in a special hospital cancer are:

1. Emergency Unit

Emergency unit or Emergency Room (ER) is a unit that treating patients with badly sick or in emergency (seriously injured) and need fast and precise handling.

In Indonesia there are some terms of emergy unit that are used, based on the hospital types [3]:

a. The Emergency (IRD) as a term applied to a class A hospital, where patients are coming can be identified and treated at the same time.

b. Emergency Room (IGD) as a term used to class $\mathrm{B}$ and $\mathrm{C}$ hospital, where the patients who come to be identified and treated. If the equipment is not adequate then the patient will be referred to the class A hospital.

c. Emergency Room (UGD) as a term applied to a class $\mathrm{D}$ hospital, health center or medical clinic. Where patients coming addressed in order P3K if necessary further treatment will be referred to the class A, B or $\mathrm{C}$ hospital then.

The conclusion, based on the statement above, Emergency units used in the class B hospital for designing cancer hospital is Emergency Room (IGD) which serve patients by identifying and treated. If they need to a special handling can be treated. If the equipment is not adequate then the patient will be referred to class A hospital.

\section{Intensive Care Unit (ICU)}

Specialist hospital unit with a special offer intensive treatment and care.

\section{Intensive Coronary Care Unit (ICCU)}

Is a specialist hospital with a special handle heart problems or sustained cardinal condition that requiring intensive supervision and treatment.

\section{Nursing Unit / Nursing Station}

grouped with a specific classification for easy supervision and care.

\section{Radiology}

Installations that use a variety of $\mathrm{x}$-ray techniques to see more detail a part of body with the purpose of diagnosis.

\section{Physical Therapy}

Management and change prevention of disease conditions involving psychiatric using special therapies.

\section{Operation room}

This facility is used to perform surgery.

\section{Delivery room}

Service and handling about pregnancy or abortion facilities.

\section{Outpatient}

Outpatient unit facilities reserved for patients who do not stay in the hospital, only a medical examination and treatment. The facilities were accommodated include a general and special clinic.

\section{Inpatient}

Inpatient facilities are used to facilitate the patient who must stay in the hospital in the curative stage and rehabilitation with 24-hour intensive care.

\section{Laboratory}

Installation laboratories provide diagnostic services.

\section{Instrument Sterilization}

Strerilization center that serves as a medical tool, receiving, sorting and processing medical instruments to be cleaned from things that can endanger the patient's condition.

13. Medical Record Department (Non-medical Departements) 
Medical record that serves as a data storage of the patient's medical records.

14. Rehabilitation Service

Providing services for patients who want to healing therapies such as physiotherapy.

\section{Laundry}

Receiving, sorting, processing of linen and dirty clothes hospital. To maintain the cleanliness and appropriateness of patient care.

\subsubsection{Architecture Biophilic}

Biophilic design is a design that is based on the aspect of biophilia, whose aim is to generate a space that can improve the welfare of human life both physically and mentally by fostering a positive relationship between man and nature. The biophilic design provides an opportunity for people to live and work in a healthy place, a minimum level of stress, and provide a prosperous life by integrating nature, either with natural materials and natural forms into the design [4].

Biophilic design seeks to create an excellent habitat for humans as in a modern environment that promotes health, fitness, and well-being [5]. The design could be done by combining elements derived from human nature that gives several benefits, such as reducing stress and improving well-being [6].

Several studies have resulted that $95 \%$ of patients and families exposed to direct contact with nature reported decreased stress degrees, better thoughts, and improved coping abilities [7]. Besides it, vegetations in rooms and rooftop gardens in hospitals increase patients' psychological reaction handling, with bringing down levels of pain, solicitude, and weariness [8][9]. Fractal structures and more broadly, natural figures and form instigate a decreasing of stress levels due to the excitant of the $\mu$-opioid receptors (MOR), which are responsible for pleasure [10].
Natural lighting impacts serotonin degrees, inducing a weakened perception of pain in patients. A $22 \%$ decrease in the use of analgesics and a $21 \%$ happen in healthcare costs was discovered. Furthermore, natural lighting has positive effects on patients undergoing chemotherapy [11][12].

Several surveys have demonstrated that the use of natural material increases the patients' perception of environmental quality and their recovery from sickness. Because this, visual comfort raise natural materials (as they absorb lighter than they reflect) and have ethical impacts on olfactory comfort (for instance through essential wood oils), creativity, overall health and the immune system [13] [14] [15].

\subsection{Study of Precedent \\ 1.4.1 Hospital Dharmais}

Dharmais Hospital was built in 1991-1993 by the foundation Dharmais, with a total area of 38 $920 \mathrm{~m}^{2}$ in Jalan Lieutenant General S. Parman, Slipi, Jakarta. Dharmais Cancer Hospital serves to provide public services equitably, especially for people with cancer [16].

Based Health Minister regulation (Permen) No. 72 / Menkes/SK/I/1993 Dharmais Cancer Hospital as the National Cancer Center, which is the center of high-references between cancer care network in Indonesia. By 1017 the total workforce consists of 100 medical personnels, 253 of the medical nurses employees, 154 non nursing paramedics employees and 510 nonmedical employees.

Dharmais Cancer Hospital is a national referral hospital in the field of cancer prevention in Indonesia, held a healing service and patient care in the plenary, education, training, research and development in the field of cancer. 
In running the task, Dharmais Hospital performs functions as:

a. Implementation of health improvement efforts.

b. Implementation of cancer prevention efforts

c. Implementation cure cancer patients.

d. Implementation of rehabilitation efforts in cancer patients

e. Implementation of care and nursing services.

f. Implementation of cancer health referral

g. Management of hospital resources

h. Implementation of education and training

i. Implementation of research and development.

j. Implementation of administration and finance.

Dharmais Cancer Hospital consists of 7 (seven) building blocks, i.e. the main building, dormitory building and research building, auditorium building, support building, general and engineering building, generator building, funeral homes and buildings, and the WWTP / STP. The main building consists of 8 (eight) floors and two (2) floors basement. Here the use of each floor of the main building are as:

a. The $2^{\text {nd }}$ basement floor is used for pump room, sewage pit and pit lifts.

b. The $1^{\text {st }}$ basement floor is used for space radio diagnostics, radiotherapy, Installation Sterilization Central (ISS) and Installation Sterilization Central Laundry (ISSB), medical records, Electronic data processing, administration and finance, computer centers, call centers, installation of outpatient (clinic specifically, the test unit's health and early detection of cancer) and human resources divisions.

c. The $1^{\text {st }}$ floor is used for the lobby, unit admission and marketing, information centers, outpatient installation (unit diagnostic integrated, diagnostic procedures, short patient unit), the emergency unit, installation of maintenance facilities, installation of clinical pathology, installation anatomic pathology, satellite pharmacy outpatient, installation mortem, cashiers, installation nutrition, kitchen and banks.

d. The $2^{\text {nd }}$ floor is used for the installation of outpatient care, medical rehabilitation, cafes and a mini market, a blood bank, a mini bank, pharmacy and satellite installation inpatient pharmacy, post office, the nurses' station, and installation of environmental health.

e. The $3^{\text {rd }}$ floor is used for the central operation room, ICU, boardroom and living room and administration.

f. The $4^{\text {th }}, 5^{\text {th }}, 6^{\text {th }}, 7^{\text {th }}$ and $8^{\text {th }}$ floor is used for patient treatment and isolation rooms and inpatient isolation of decreasing immunity patients and radio active (specifically the $5^{\text {th }}$ floor).

The Dharmais Hospital production and supporting unit consists of:

1. Medical Services Unit

a. Outpatient Installation.

b. Integrated Diagnostic Unit (UDT).

c. Diagnostic procedures Unit.

d. Oncology Clinic Unit.

e. BRIEF Care Unit.

f. Private Polyclinic Unit or Special.

g. Inpatient unit.

h. Inpatient unit VVIP with 2 (two) beds

i. Inpatient unit VIP consisting of 14 (fourteen) beds.

j. Inpatient unit class I, consisting of 36 (thirty six) beds.

k. Inpatient unit Class II, consisting of 37 (thirty-seven) beds

1. Inpatient unit Class III, consisting of 52 (fifty-two) beds.

m. Inpatient unit Soka consisting of 20 (twenty) beds.

n. Inpatient unit children consisting of 15 (fifteen) beds.

o. Isolation rooms decreasing immunity.

p. Inpatient unit of Radio active isolation.

2. Intensive care unit.

3. Emergency Room.

4. Central surgery Installation.

5. Radiotherapy Installation. 
6. Supporting medical unit:

a. Radio diagnostic installation.

b. Endoscopy Installation.

c. Medical rehabilitation Installation.

d. Pathology clinic and microbiology Installation.

e. Anatomical pathology Installation.

f. Blood bank and aphesis Installation.

g. Pharmacy Installation.

h. Early detection and Social oncology Installation

7. Non-medical support unit

a. Human resources and education

b. Medical Record

\subsubsection{The MRCC Siloam Hospitals Semanggi}

Starting from the first hospital in Lippo Village in 1996, the Company has developed into the largest hospital group in Indonesia with 16 hospitals state-of-the-art, which is supported by 1,500 physicians and 6,000 employees [17].

On September 12, 2013, the Company has changed its name to PT Siloam International Hospitals do an Initial Public Offering (IPO) and listed on the Indonesia Stock Exchange as PT Siloam International Hospitals Tbk.

As of December 31, 2012, according to Frost and Sullivan, Siloam Hospitals Group is the largest private hospital group in Indonesia in the number of bed capacity and number of operations. Aside from hospital beds, Siloam Hospitals also became the first hospital in Indonesia that received international accreditation from the Joint Commission International Accreditation (accreditation was carried out in 2007, 2010 and 2013). Accreditation strengthen the position of Siloam as a hospital with international standard services.

At the end of 2013, Siloam Hospitals operates 16 hospitals, in the stage of 21 hospitals building construction (4-5 operates in 2014) and build 19-20 hospitals during 2015-2017.
Capacity of 331 beds and 122 operational beds, with 130 specialist doctors, 29 general doctors and 237 nurses with the number of 38 floors.

The production and supporting unit of MRCC Siloam Semanggi Hospital as follows:

1. Non-medical support unit

a. Human Resources.

b. Medical records.

c. Information Systems.

d. Maintenance of facilities Installation.

e. Nutrition installation.

f. Logistics installation.

g. Central sterilization installation.

2. Medical Service Unit.

a. Inpatient.

b. Outpatient.

3. Intensive care unit

4. Emergency Room.

5. Central surgery Installation.

6. Radiotherapy Installation.

7. Medical support unit

a. Medical rehabilitation Installation.

b. Pharmacy Installation.

\subsubsection{Singapore's Khoo Teck Puat Hospital (KTPH): Biophilic Design in Action}

The most biophilic hospital in Asia, Singapore's Khoo Teck Puat Hospital (KTPH). In no any hospital of this scale are elements of form, space and landscape so explicitly tied to applied biophilic design.

Biophilic design set in motion a quest that expanded into five principles:

- $\quad$ Sight, Visual access to greenery and water;

- Smell, Selection of scented plants;

- Sound of falling water;

- Diversity of plants, birds and butterflies;

- Community, Public space situated within the blue-green areas [18].

\section{Materials and Methods}


The discussion method used is a design exploration by outlining the existing problems through the study of literature, precedent studies, and field surveys, linking it with some influential variable, so it can be formulated as a reference to be used as the transformation into the design.

a. Study of literature, at this stage, the authors take the review of literature in the form of data collection of books related to the cancer hospital and also to get a theory Biophilic architecture, specifications, and characteristics and aspects that may be invoked in the design.

Table 1. Summary by Precedent Studies

\begin{tabular}{|c|c|c|c|c|}
\hline \multirow{2}{*}{$\begin{array}{c}\text { No } \\
\text {. }\end{array}$} & \multirow[t]{2}{*}{ Name } & \multicolumn{3}{|c|}{ Hospital } \\
\hline & & Dharmais & $\begin{array}{l}\text { MRCC } \\
\text { Siloam }\end{array}$ & КTPH \\
\hline 1 & Building & $8+2$ Basement Floors & 38 floors & Sight, Visual access to greenery and water; \\
\hline 2 & Zoning & $\begin{array}{c}\text { Floor } 2 \text { Basement: } \\
\text { Service } \\
\text { Floor 1 Basement: } \\
\text { Administration } \\
\text { Level 1: Outpatient } \\
\text { Level 2: Hospitalization } \\
\text { Floor 3: Surgical Center } \\
\text { Floors 4-8: } \\
\text { Hospitalization }\end{array}$ & & $\begin{array}{l}\text { Smell, Selection of scented plants; } \\
\text { Sound of falling water; } \\
\text { Diversity of plants, birds and butterflies; } \\
\text { Community, Public space situated within the } \\
\text { blue-green areas. }\end{array}$ \\
\hline 3 & Bed & 178 & 331 & \\
\hline
\end{tabular}

\section{Results and Discussions}

Site Location of cancer hospital design is in J1. Teuku Cik Ditiro, Beringin Raya, Kemiling, Bandar Lampung, Lampung Province. According to Rule of Bandarlampung Regional Regulation (RTRW) No. 10 of 2011 about Spatial Plan Year 2011-2030 explained that Sub City Service Center (FIES), sub-Kemiling serves as a particular education area (Police or State Police School), agro-tourism and ecotourism, trade and services, protected areas and conservation, limited shelter/ housing, higher education, and sports center.

The accessibility and circulation problem is the road to the site still has holes, and that cause of travel time to the site can be blocked. Around the site can not be found congestion because this area is relatively quiet. The accessibility b. Study of precedent, at this stage of the study authors, take precedence over the internet about cancer hospital building in Indonesia and Singapore, which is divided into (a). Precedent studies following the design. (b). Precedent Studies appropriate with design application.

c. Study of the field, at this stage to determine the field surveys and observing and collecting information about the potential of the physical and non-physical location of the design from the site to the city center of Bandarlampung and the transport hub will not take much time.

Environmental activities around the site tend to be quiet because it is close to the protected forest areas. The housing area around the site is still under developing while a condition of land on-site is contoured partly.

Human behavior tends to be less concerned about the environment surrounding the area. Whereas if they can take care of the surrounding environment, such as not cutting down trees, can be one of the healing therapies in the health field. Effect of improper waste disposal standards when operating cancer hospitals can make public health in the vicinity and can be disturbed. 
Circulation in and out of the building can meet all the activities of the patient, medical personnel, their families, health equipment, and vehicles. The parking lot is prepared quite widely order so that not to disturb the activities on the site. They are using environmentally friendly material and laying a building to be easily achieved and designing the buildings to meet the health building standards.

\subsection{Site and Environmental Aspects}

Site area of Cancer Hospital is 4.5 hectares $\left(45,000 \mathrm{~m}^{2}\right)$. KDB (Basic Building Coefficient) is $27.000 \mathrm{~m}^{2}$. RTH (Green Open Space) is $18.000 \mathrm{~m}^{2}$. KLB (Coefficient Building Floor) is $68,800 \mathrm{~m}^{2}$. GSB (Line Border Building) is $8 \mathrm{~m}$.

\subsection{Site Neighborhood Analysis}

The location election of the cancer hospital site Kemiling area is easily accessible. Kemiling areas, including areas that will evolve, close to the protected forest areas and mountains, making it suitable to apply the concept of Biophilic.

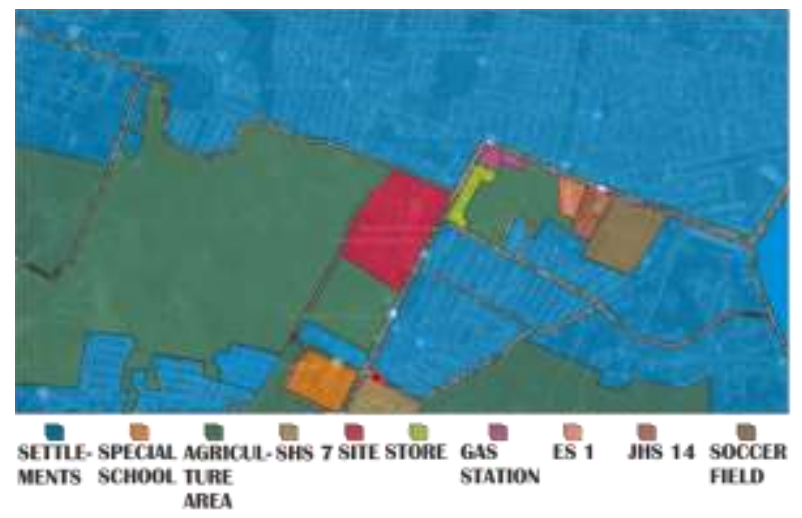

Figure 2: Site Neighborhood

\subsection{Environmental Characteristics}

The environment around the site have building characteristics with modern design in residential building and shop building has a modern design as well. This analysis aims to create harmony between the design and the cancer hospital in the surrounding environment, somewhat contradictory.

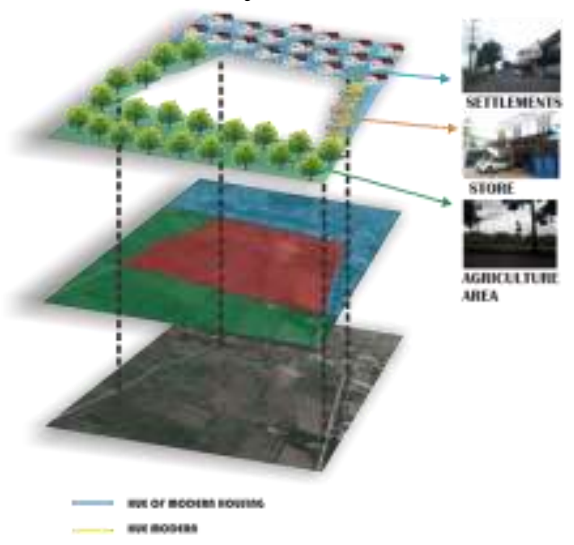

Figure 3: Environmental Characteristics

\subsection{Drainage Analysis}

Analysis of drainage on the site aims to determine the flow of the produced water disposal rainwater. Rainwater on the site tends to fall toward the north so that the northern part of the site could be used to collect rainwater from being wasted. The preferred solution is to create a forest to overcome puddle biopore by utilizing soil absorption in water, fertilize the soil. The second solution by creating a reservoir with water at the destination can be for the building supporting watering such as water to the hydrant.

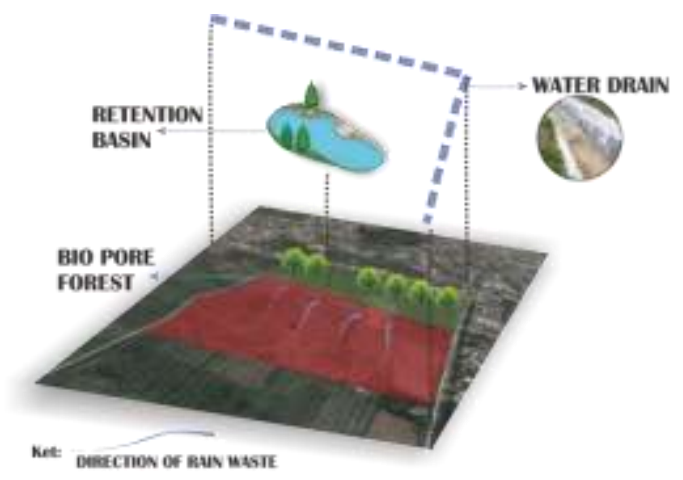

Figure 4: Drainage Analysis

3.5 View Analysis 
Analysis of view aims to know the views around the site, and this analysis can be a reference orientation of the shape of the building to achieve people's comfort both inside and outside of the Site. The main point of view on a site that is located in the southern site that leads to Mount Betung that perfectly fits with the theme of the Biophilic design.

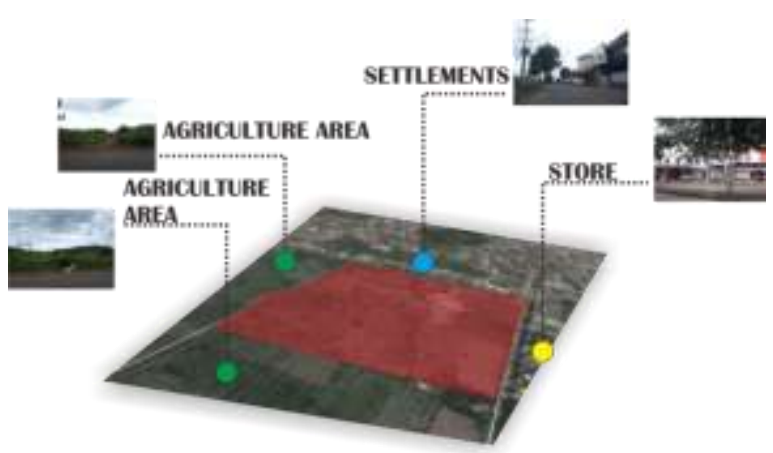

Figure 5. View Analysis

\subsection{Noise Analysis}

Analysis of noise at the site aims to determine the level of noise in the vicinity of the site so that the laying of the building, which has a very high level of quietness is not close to the center of the noise. The highest noise is the east site that is close to Jl. Teuku Cik Ditiro. Solutions in the north could plant crops that can reduce the number of noise examples that can be used tree is a tree headland. The second solution is to put the building such as the examination room, the recovery room, the surgery room bit away from the primary noise source.

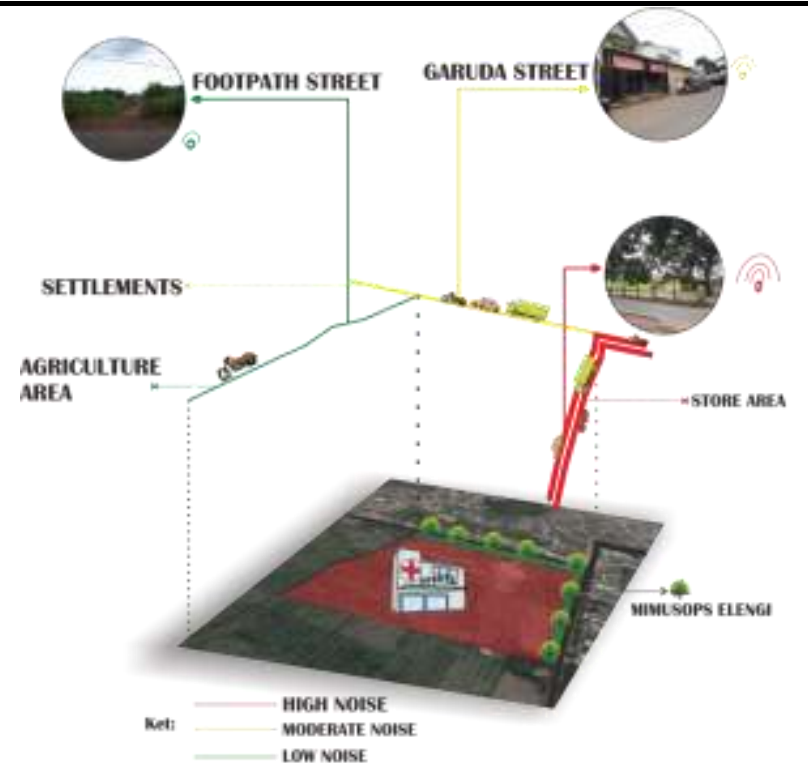

Figure 6: Noise analysis

\subsection{Sun Path Analysis}

Analysis of sun path aims to take advantage of solar energy as much as possible, not wasted unnecessarily. The solution to this is by using solar panels, which then channeled the energy gained for electricity outside of the building, such as street lights and garden lights. If the energy learned quite a lot to help the power source for the building. The trees were planted in the site could be one solution to cool the hospital building, so that it can minimize the use of air conditioning.

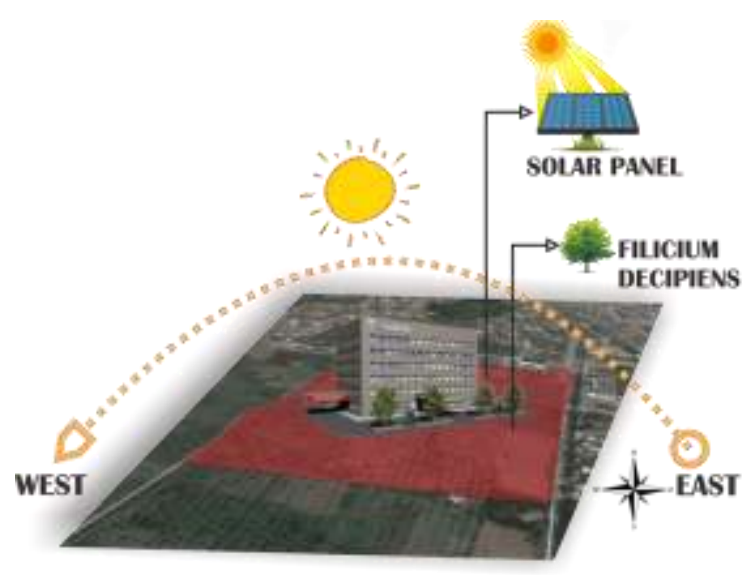

Figure 7: Sun Analysis 


\subsection{Wind Analysis}

Analysis of the wind direction at the site aims to harness wind potential for the building site. The direction of the wind's circulation at the site from the southwest to the northeast with average intensity. Wind direction can be used to grow a bamboo plant. Bamboo is believed to give soothing sounds when exposed to the wind. Another solution is to plant trees that were planted in the stacking pattern for directing air into the building in order to create the natural air and can indirectly save on electricity usage of the building.

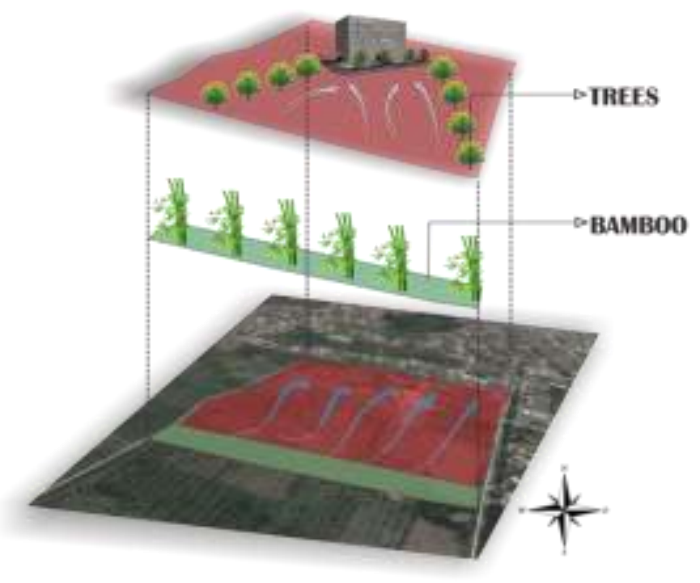

Figure 8: Wind Analysis

\subsection{Accessibility Analysis}

Accessibility analysis aims to determine which path is impassable by road users into the site. Jl. Teuku Cik Ditiro a secondary collector road is a road that connects between the second secondary area or connecting the second secondary region with the third secondary region. This path can be used as the main entrance to the site. Jl. Garuda is a local roadie local road serving local transport to travel a short distance, the average speed is low, and the number of driveways is not restricted. This path can be used as an alternative way out of the vehicle. The walkways are made the way citizens with a view to the location of the farm.
This road can be a solution when one day Jl. Garuda became stalled-out access.

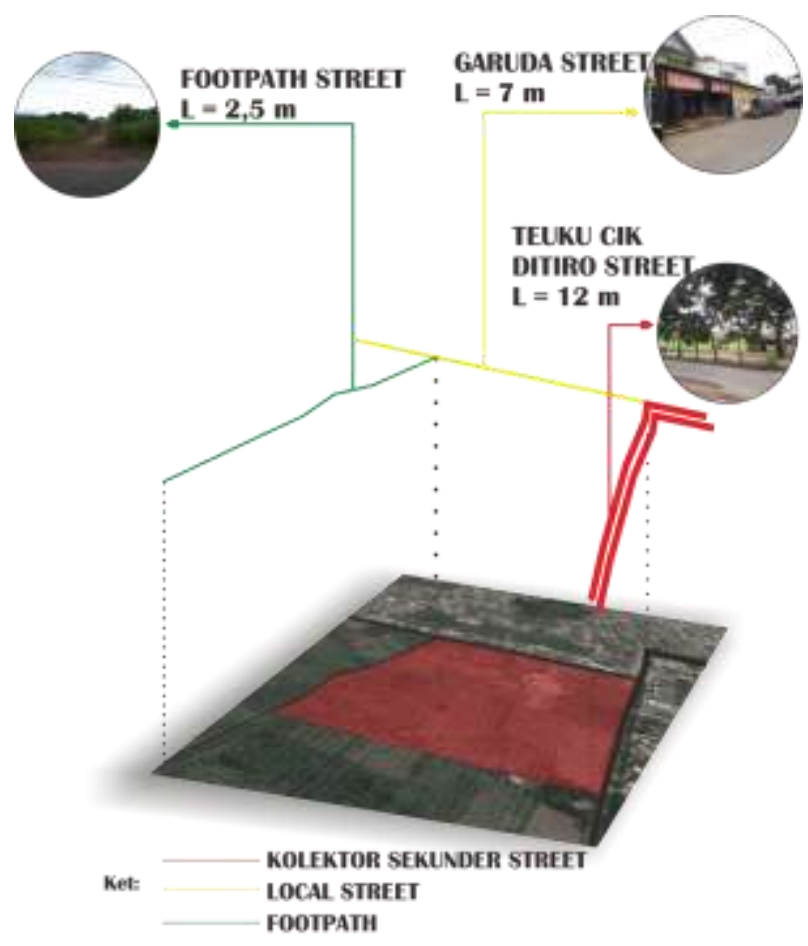

Figure 9: Accessibility Analysis

\subsection{Vegetation Analysis}

Analysis of vegetation on the site aims to take advantage of existing plants in it that are not removed because waiting for a tree to be growth takes a couple of years. At this site, the trees that can not be used because of site area covered by farmland plants. The solution to this condition is to leave some crops in a site that is likely to be an object for the treatment of patients in the future. Or it could be an agricultural crop is taken one sample to be collected into a zone for being the object of therapy plantations. 


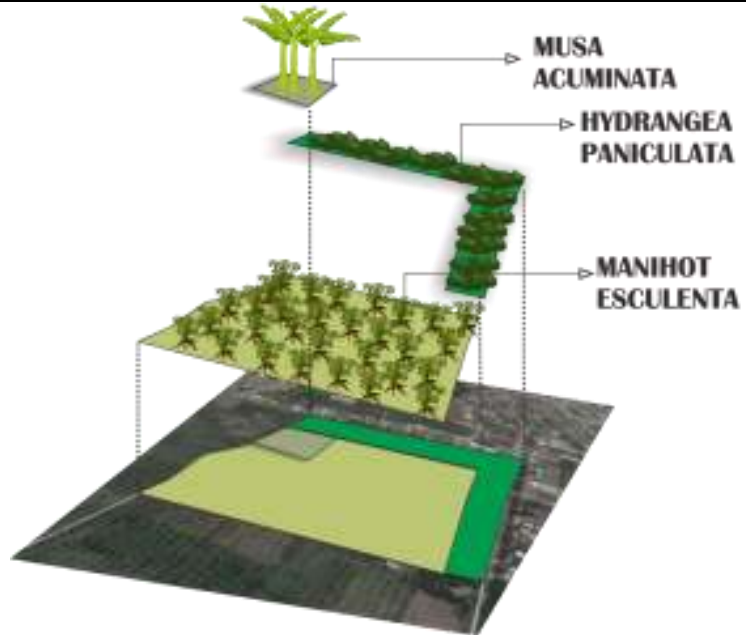

Figure 10: Vegetation Analysis

\subsection{Aspects of Circulation}

Circulation at IGD space is divided into three, namely doctors and nurses, patients, and their families. Patients and families of patients coming through the lounge and admin. The patient goes through a triage room. From the triage room, there are three lanes, can the action space, to examination and observation. Examination and observation of space, there are two lines, ie, to the preparation room and could be straight out. From bedroom to room, prepare IBS while doctors and nurses enter through the room, doctors, and nurses to the tool room, a triage room, and into the action space.

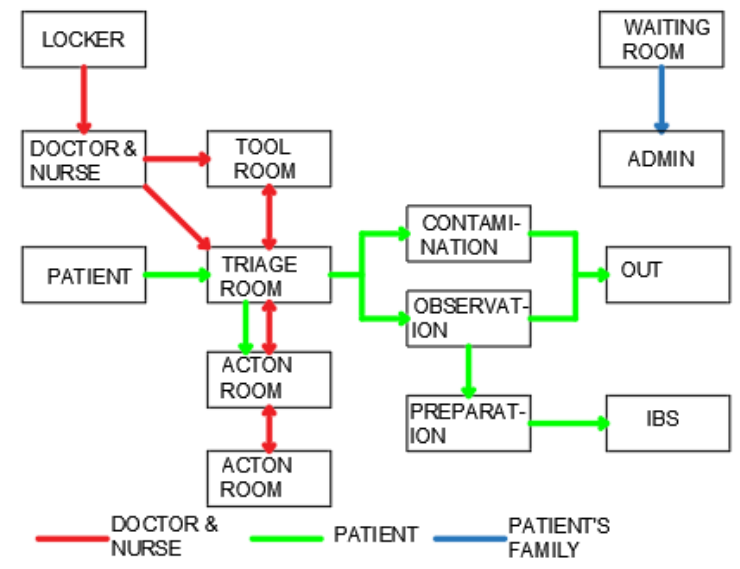

Figure 11: IGD Circulation
Outpatients can go through the registration room and lounge area. Then go to the doctor's office. From the doctor's office for administrative space and to the pharmaceutical space.

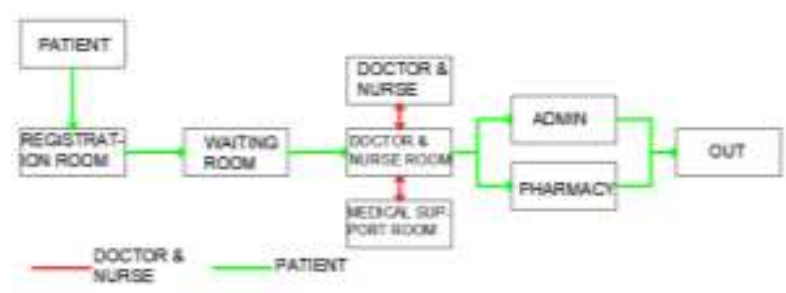

Figure 12: Outpatient Circulation

Circulation at the central surgical patients in the waiting room, then to the administration, into the preparation room. From the entrance hall to the operating room preparation. After the surgery, go to the recovery room and ICU. In this room, the doctors and nurses went into the locker room, then to scrub station and into the operating room. While officers can clear the operating room and into the dirty utility room and forward it to the CSSD.

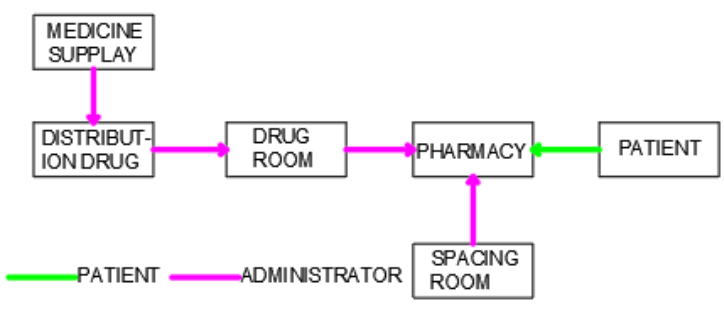

Figure 13: Central Surgery Circulation

The clerk at the pharmacy beginning of drug supply room, then later saved drug distribution in space medicine. There are medications that go directly to the pharmacy, but there are also medications that are formulated in advance on the work surface. While the patient can directly take the drug to pharmacies by providing recipes and wait invoked. 


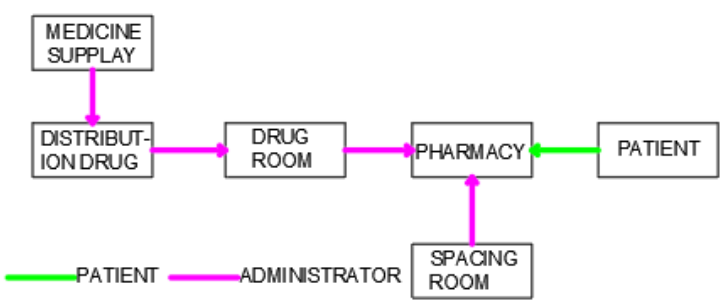

Figure 14: Pharmaceuticals Circulation

In the radiology room, doctors and nurses coming from the doctor's office to the consulting room then went into the examination room and the CT Scan and X-Ray. Whereas patients could come from the emergency room, outpatient and inpatient through administrative space, and then into the lounge. From the waiting room into the consulting room or directly into an examination room and a CT Scan and X-Ray.

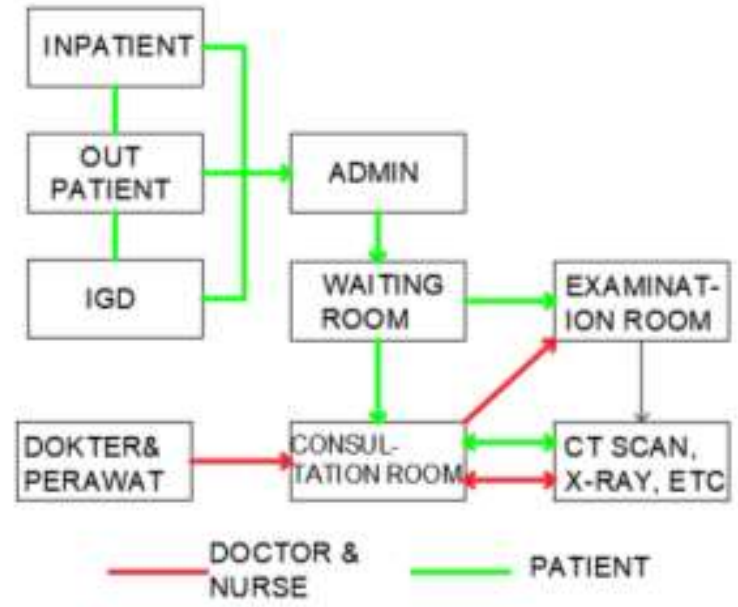

Figure 15: Radiology Circulation

Patients will enter the dating laboratory space through the waiting room, then to the administrative space from an administration into the EEG / USG or the sample chamber. Existing samples tested in the laboratory by a doctor/nurse/attendant lab. Results of laboratory space at the input to the distribution of which will be delivered directly to the patient or by doctor/nurse.

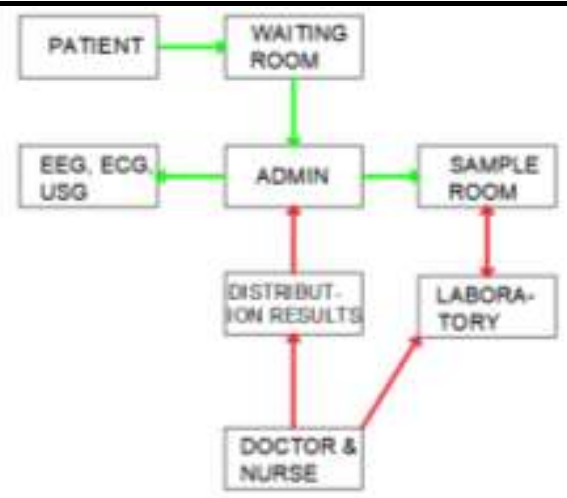

Figure 16: Laboratory Circulation

Circulation in the rehabilitation room medic in which patients and doctors/ nurses went into rehabilitation medic. Doctor/ nurse can access the tool room.

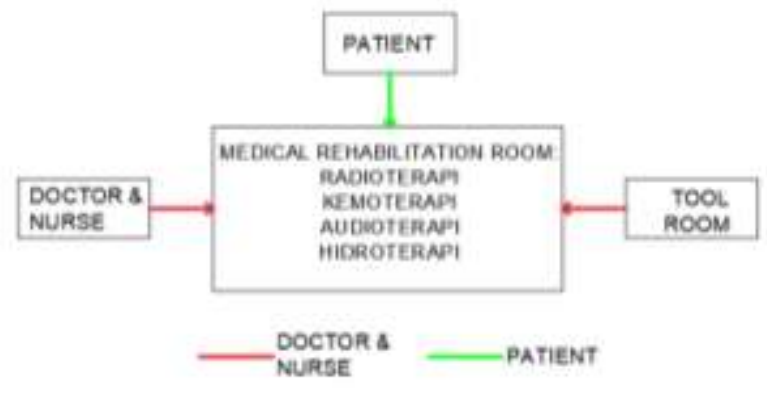

Figure 17: Medical Rehabilitation Circulation

Circulation of patients in the intensive care which starts with a waiting room, and then into the transfer chamber. From the transfer chamber into the room nurse station and forwarded to the intensive care unit. While doctors and nurses went into the locker room, then went into the nurse station. From the space station nurse can go to the intensive care unit and into the dispensary. 


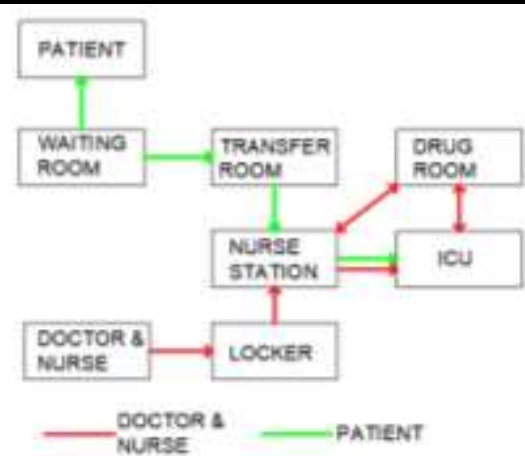

Figure 18: Intensive Care Circulation

CSSD space used only by officers, where officers receive in space [enerima, then enter the sterilization chamber. From the sterilization chamber into the distribution space or get into the storage room.

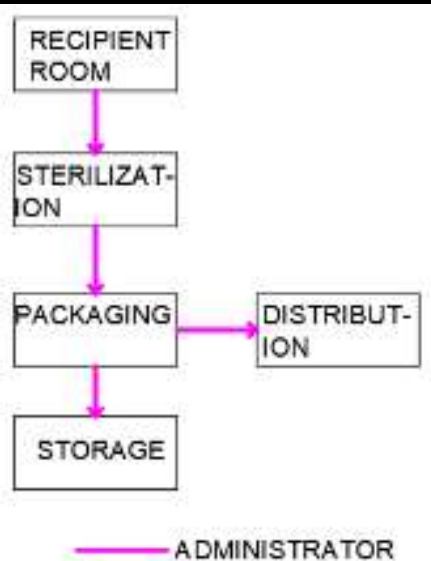

Figure 19: Central Sterile Supply Department (CSSD) Circulation

\subsection{Space Needs Analysis}

Table 1. Space Needs Analysis

\begin{tabular}{|c|c|c|}
\hline Space Name & Area $(\mathrm{m} 2)$ & Zone \\
\hline Outpatient Installation & 1,719 & semi-public \\
\hline Emergency departments & 2,093 & semi-public \\
\hline Inpatient & 5597 & semi-public \\
\hline Installation Intensive Care & 834.4 & Privat \\
\hline Installation of Central Surgery & 1923.6 & Privat \\
\hline installation Radiotherapy & 648.2 & Privat \\
\hline Installation of Central Sterilization (CSSD) & 372.4 & Service \\
\hline Pharmacy & 435.4 & semi-public \\
\hline Laboratory installation & 435.4 & semi-public \\
\hline Installation Pemulasaran Jenazah & 915.6 & semi-public \\
\hline Installation Blood Transfusion / Blood Bank & 316.4 & semi-Public \\
\hline Major Kitchen Installation Clinic & 252 & Service \\
\hline Sanitary installations & 466.2 & Service \\
\hline Installation Pencucuian Linen / Laundry & 232.4 & Service \\
\hline $\begin{array}{l}\text { Installation Maintenance Facility (Mechanical and } \\
\text { Electrical Workshop / Workshop) }\end{array}$ & 179.2 & Service \\
\hline Facilities On PenunjangUmum and Administration Area & 330.4 & semi-public \\
\hline \multirow[t]{2}{*}{ Installation Medical Rehabilitation } & 1233.4 & privat \\
\hline & Total $=17984.3 \mathrm{~m} 2$ & \\
\hline
\end{tabular}

\subsection{Site Zoning}

Site zoning of cancer hospital is divided into four public services, semi-public and private can be explained as follows, public Zoning includes green open areas such as parks, parking of vehicles, ponds. Semi-public and public building covers an area of hospital cancer. Services include treatment areas and improvements in the cancer hospital building. 


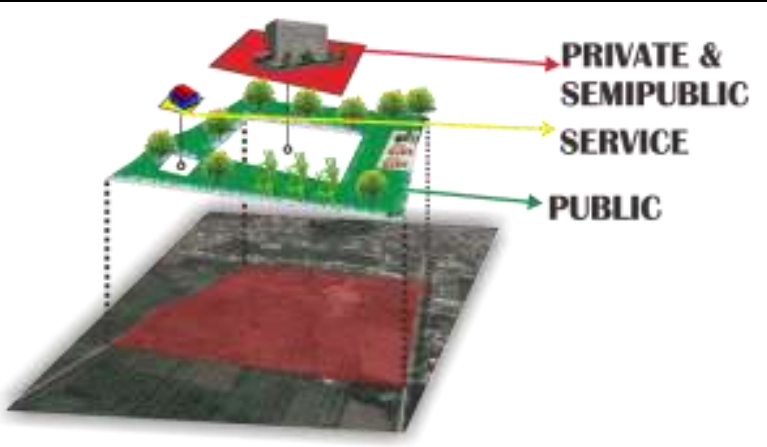

Figure 20: Site Zoning

\subsection{Building Zoning}

Zoning at the cancer hospital building consists of semi-public, private, and service. Zoning first floor consists of semi-public include the emergency department, outpatient installation, installation of laboratory, pharmacy, blood bank installation, installation of Scavenging of Corpses, amenities In General and Administrative Support Area. Zoning laundry services consisting of installation, kitchen installation clinic, CSSD installation. Zoning second floor consists of private includes the installation of central surgical, intensive care facilities, the installation of radiotherapy, installation of medical rehabilitation. Zoning third floor consists of a semi-public include inpatient unit.

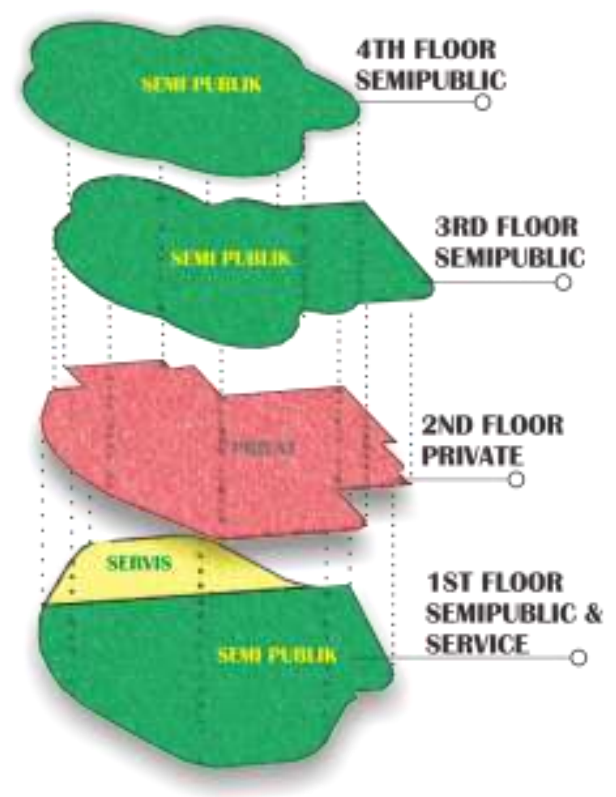

Figure 21: Building Zoning

\subsection{Building Mass Concept}

Mass Concept of building transformed from the shape of the logo Bakti Husada meaningful dedication of comprehensive health, age composition taken on the looks of the building. Green Cross logo Husada devotion applied to form voids in the ground floor into the pool and building core. Green Cross applied to the roof covering per level. Flowers Wijayakesuma applied on the 4th floor of the building form.

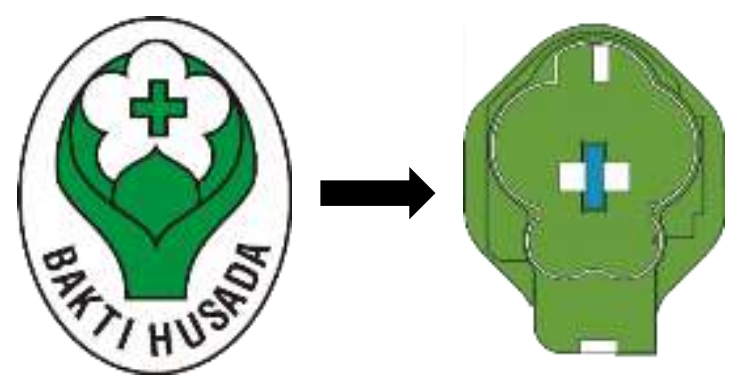

Figure 22: Building Mass Concept

\subsection{Circulation Concept}

Access into the site has three entrances, which consists of service and the employee entrance, the entrance to the emergency room, and the entrance of the patient. Objective 3 entrance made access to no buildup of the vehicle because the hospital must have quick access without the freeway.

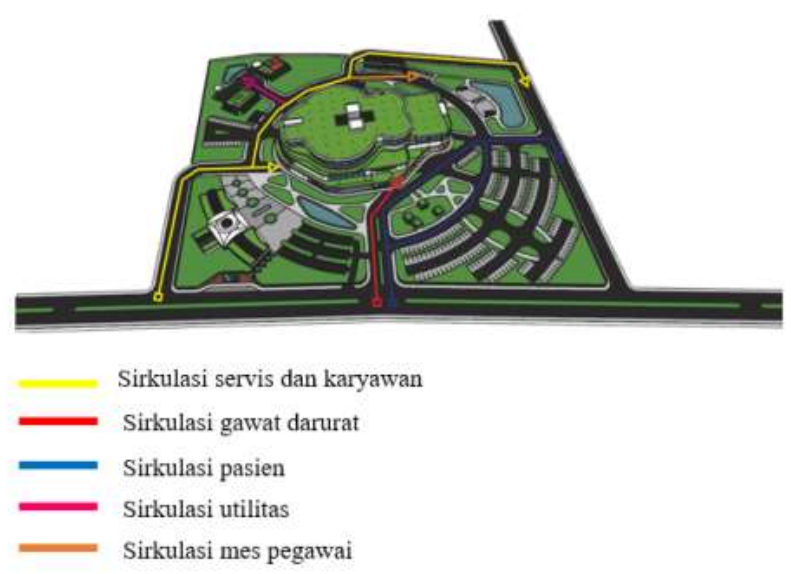

Figure 23: Circulation Concept 


\subsection{Implementation of Biophilic Architecture Concept}

Biophilic concept applied to the design of the lounge area in which there are voids leads directly to the pool below, wall coverings made of natural wood that seem deliberately not solid so sunlight can get into the room.

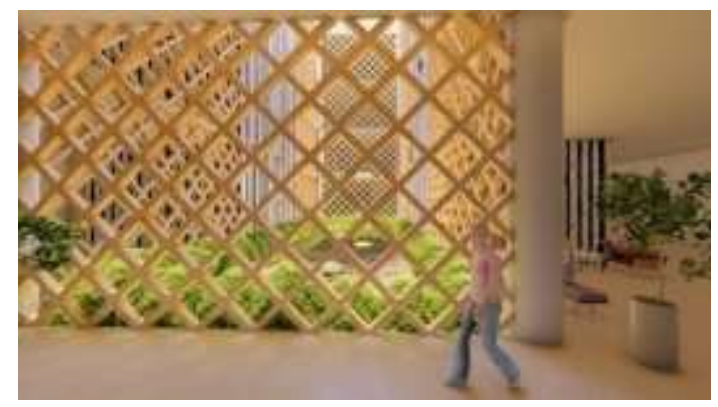

Figure 24: Biophilic Concept in Waiting Room

3rd and 4th floor is a space hospitalization of patients using a glass that can be opened that serves to incorporate light and the natural air. Used color blue glass for the purpose of applying the color of sky and water.

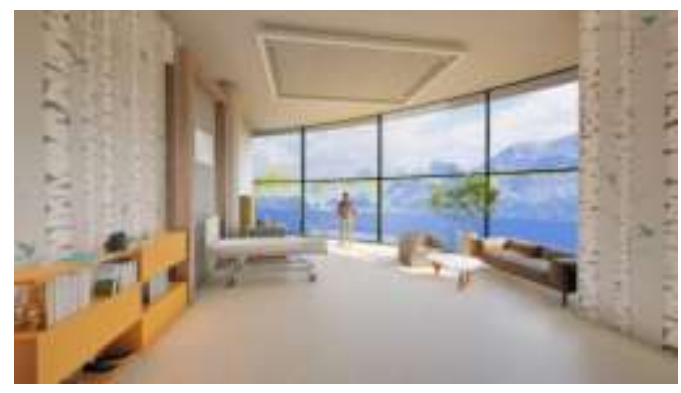

Figure 25: Biophilic Concept in Patient Room

Biophilic architecture concept implementation on site can be seen when the patient enters the hospital neighborhood atmosphere to be conveyed to the patient in a natural setting. The first impression when entering hospital patients does not think negative, Because of indirect natural vibes seen by the patients who want to do a treatment.

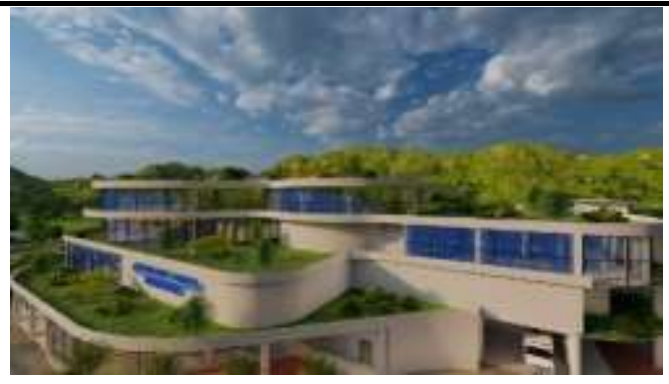

Figure 25: Biophilic Concept on Building

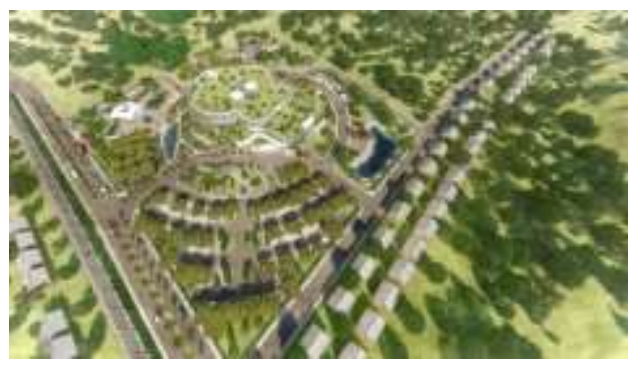

Figure 26: Concept Biophilic on Site

\subsection{Vegetation Concept}

Plant not only serves to embellish atmosphere and as a shade, but plants also have efficacy as a medium for accelerating the healing process pain. Plants used as aromatherapy is a plant of jasmine and rose, jasmine plant scent is believed to accelerate the process of curative, can relieve depression, stimulate nerves work. Mimosa pudica plant that can grow wild in roadside believed to relieve depression, stimulate nerves and pain relievers.

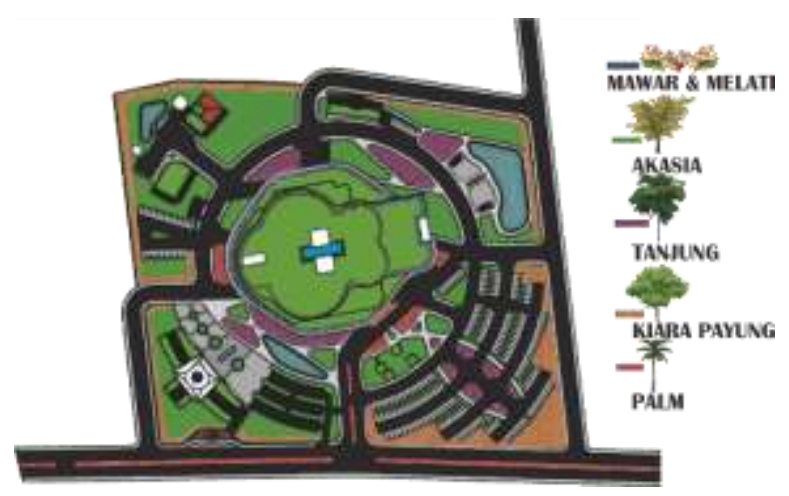

Figure 27: Vegetation Concept 
Plants that become the design concept on the site are Ketapang and acacia trees, which serve as shading. Plants that serves as a producer of oxygen is a palm, acacia, Kiara Payung (Filicium Decipiens) and Tanjung trees. Plants that help to invite the animal are Kiara Payung trees, acacia trees, and Jarak Hias trees. Vegetation for reducing noise is Kiara Payung trees and acacias.

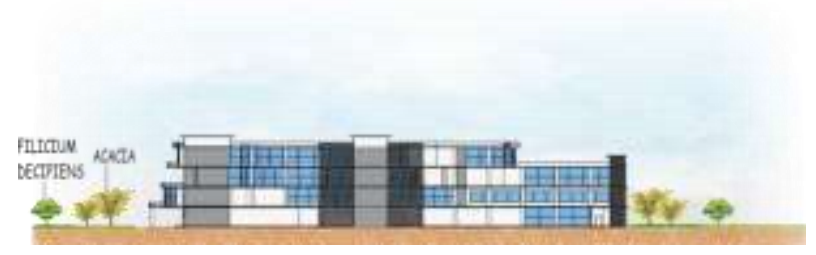

Figure 28: Section of Vegetation Concept

\subsection{Color Concept}

The color concept on the building has its appeal in human psychology and buildings. Building with blue glass that influences the psychology of the patient in the form of repellent pain and disease. The white color on the walls of the building has the effect of cleanliness, vibrant, and a source of pure mind. Brown color contained in the outer lobby of the building has the effect of comfort and confidence.

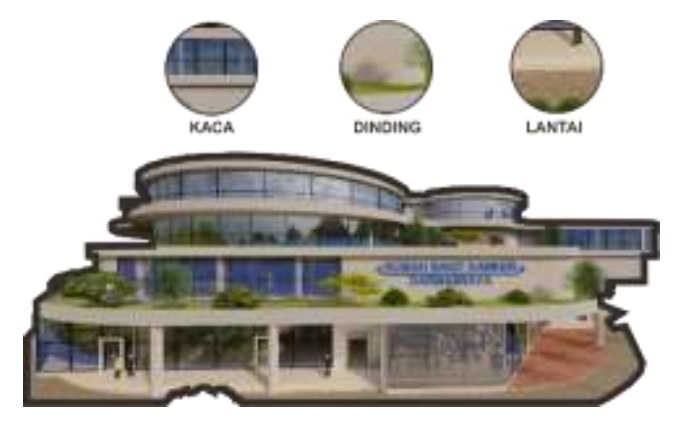

Figure 29: Color Concept

\subsection{Supporting Facilities Concept}

The concept of placement of supporting facilities building, parked vehicles, plazas and ponds takes the concept of radial, scattered from one point which is building a hospital.

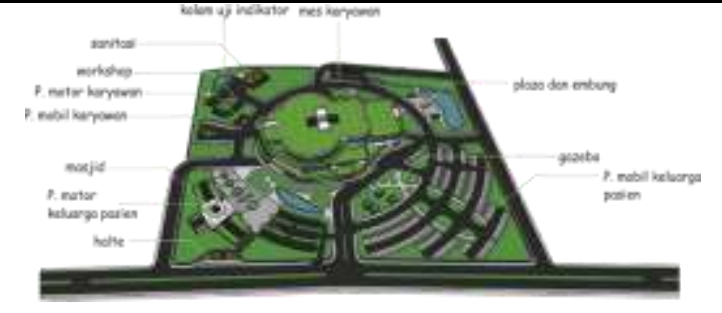

Figure 30: Supporting Facilities Concept

\subsection{Structural Concept}

Building foundation using bore pile, thus the structure can withstand the load from the top of the building, coupled with the cores on the edge of the building and the center of the building as a stiffener structure. Use of the system dilatation on the structure of the building to avoid structural damage due to ethical and horizontal force arising from the movement of soil, and earthquake. The concept of dilatation with the console.

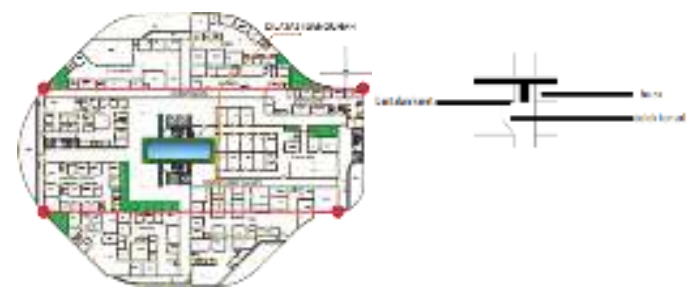

Figure 31: Structural Concept

\subsection{Utility Concept}

Clean water of hospital piped and taken from rainwater absorption.

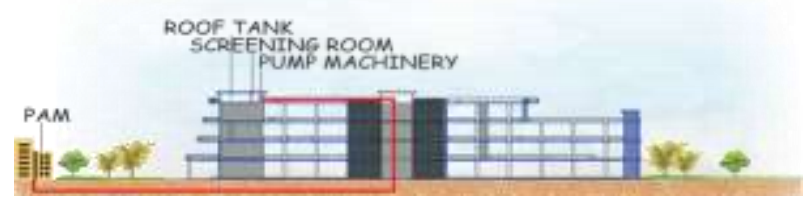

Figure 32: Clean Water Concept

Hospitals waste is divided into clinical waste sharps waste, infectious waste, waste of tissue, Citoksis waste, pharmaceutical waste, chemical waste, radioactive waste, and plastics waste. 
The handling of waste is divided into combustion/ incinerator and wastewater treatment. Waste disposal of hospital buildings going to piped sanitation has directly led to the installation and garbage shaft that has been provided. Results of wastewater treatment are channeled into the pond indicator test first when it is feasible and not detrimental to health will be distributed back to the reservoir in area hospitals and the city's drainage channel

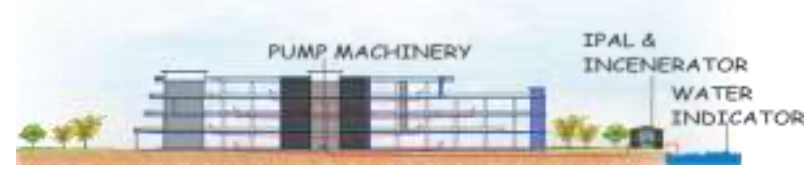

Figure 32: Wastewater Concept

\subsection{Fire Protection System Concept}

Fire protection systems in buildings using an automatic mechanism. In this system, the equipment works automatically, either to detect fire hazards and then immediately give the alarm, as well as in addressing the/ extinguish the fire. Because the equipment works automatically, then the self-prevention and fire hazard protection can take place quickly, and the possibility of expansion of the area of the fire and its consequences can be reduced as much as possible. Multi-story buildings mostly using an automated system, in addition to faster and more efficient working.

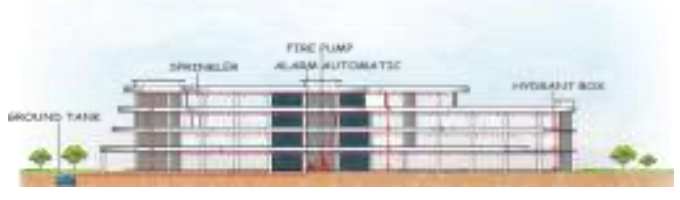

Figure 33: Fire Protection Concept

\subsection{Electricity Network Concept}

The electrical grid design took most of the PLN and partly used solar panels that placed on the roof of the building. Electricity in the area of the hospital if outages should not be too long because it will interfere with the activities in the hospital. The use of generators at the hospital is a solution in case of a power outage, and the generator used must be able to relive the electric hospital in a matter of seconds..

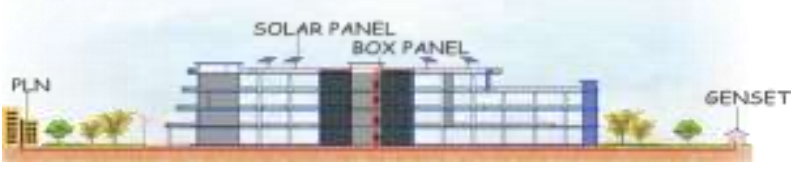

Figure 34: Electricity Network concept

\section{Conclusion}

The results showed that the Biophilic concept could be applied to the waiting room, inpatient unit, and site. In the waiting room, there is a void that leads directly to the pool below, wall coverings made of natural wood that seem deliberately not solid. So sunlight can get into the room. Inpatient unit room using a glass that can be opened that serves to incorporate light and the natural air. It used blue glass color to apply the color of the sky and water. On the site can be seen when the patient enters the hospital neighborhood atmosphere to be conveyed to the patient in a natural setting so that the first impression when entering hospital patients is not negative thinking.

This research is limited to the application of Biophilic Architecture concepts in waiting rooms, inpatient rooms, and sites. Further research is needed regarding the application of Biophilic concepts in outpatient facilities and another facility.

\section{Acknowledgement}

The authors thank Universitas Bandar Lampung for providing facilities for conducting the research. The authors also thank the International Journal of Built Environment and Scientific Research (IJBESR) Universitas Muhamadiyah Jakarta for helping us to publish the results of this research. 


\section{References}

[1] Kemenkes RI. Riset Kesehatan Dasar (RISKESDAS) 2015. Jakarta: Kemenkes RI; 2015.

[2] Departemen Kesehatan RI. Peraturan Mentri Kesehatan Republik Indonesia No340/MENKES/PER/III/2010 Tentang Klasifikasi Rumah Sakit. Jakarta; 2010

[3] Idji, Berni. Pola Aksesibilitas di Instalasi Gawat Darurat Rumah Sakit. Yogyakarta: Thesis MDKB UGM; 2012.

[4] Ryan, C.O., W.D. Browning, J.O. Clancy, S.L. Andrews, \& N.B. Kallianpurkar. Biophilic Design Patterns: Emerging Nature-Based Parameters For Health and Well- Being In The Built Environment. Archnet International Journal of Architectural Research, 2014; 8 (2), p-62-76.

[5] S. Kellert and E. Calabrese. The Practice of Biophilic Design; 2015.

[6] Octavianti AS, Sardiyarso ES, Iskandar J, Wulandari MIR. Komparasi Konsep Pola Analogi Alam Biofilik Desain di Bangunan Pendidikan. Seminar Nasional Cendekiawan ke 4 2018; p-69-75.

[7] Marcus CC, Barnes M. Gardens in healthcare facilities: uses, therapeutic benefits, and design recommendations. The Center for Health Design, Concord; 1995.

[8] Park SH, Mattson RH. Effects of flowering and foliage plants in hospital rooms on patients recovering from abdominal surgery. Horttechnology 2008;18:p563-568.

[9] Matsunaga K, Park BJ, Kobayashi $\mathrm{H}$ et al. Physiologically relaxing effect of a hospital rooftop forest on older women requiring care. J Am Geriatr Soc 2011;59:p-2162-2163.

[10] Biederman I, Vessel EA. Perceptual pleasure and the brain: a novel theory explains why the brain craves information and seeks it through the senses. Am Sci 2006; 94:p-247-253.

[11] Walch JM, Rabin BS, Day R, Williams JN, Choi K, Kang JD. The effect of sunlight on post-operative analgesic medication usage: a prospective study of patients undergoing spinal surgery. Psychosom Med 2005;p-67:156-163.

[12] Liu L, Marler M, Parker BA, Jones V, Johnson S, Cohen-Zion M, Fiorentino L, Sadler GR, Ancoli-Israel S. The relationship between fatigue and light exposure during chemotherapy. Support Care Cancer 2005;13:p1010-1017.

[13] Tsunetsugu Y, Miyazaki Y. Measurement of absolute hemoglobin concentrations of prefrontal region by near infrared time resolved spectroscopy: examples of experiments and prospects. J Physiol Anthropol Appl Hum Sci 24(4) 2005;p-469-472.
[14] Li Q. Effect of forest bathing trips on human immune function. Environ Health Prev Med 15(1) 2010;p-9-17.

[15] McCoy JM, Evans G (2002) The potential role of the physical environment in fostering creativity. Creativity Res J 14(3-4)2002;p-409-426.

[16] https://www.dharmais.co.id/ [Accessed on March $\left.20^{\text {th }} 201910.00 \mathrm{am}\right]$.

[17] https://www.siloamhospitals.com [Accessed on March $\left.20^{\text {th }} 201910.00 \mathrm{am}\right]$.

[18] https://blog.interface.com/khoo-teck-puat-hospitalsingapore-biophilic-design/ https://www.dharmais.co.id/ [Accessed on March 20 $201910.00 \mathrm{am}$ ]. 
(This page is intentionally left blank) 